\title{
How to Improve Vocational Teachers' Understanding in Governmental Accounting? An Experimental Study on Accounting Teachers from Vocational Schools in West Sumatera Province
}

\author{
Vita Fitria Sari ${ }^{1}$, Mayar Afriyenti ${ }^{2}$, Mia Angelina Setiawan ${ }^{3}$ \\ ${ }_{1}^{1}$ Universitas Negeri Padang, Padang, Indonesia, $\square$ vitafitriasari@gmail.com \\ 2Universitas Negeri Padang, Padang, Indonesia, $\square$ mayarafriyenti@gmail.com \\ ${ }^{3}$ Universitas Negeri Padang, Padang, Indonesia, $\square$ miaangelinasetiawan@gmail.com
}

\begin{abstract}
Since the issuance of the new curriculum structure mentioned in SK Dirjen Dikdasmen No.130/D/KEP/KR/2017 brought many changes in curriculum structure include for vocational schools. Especially in accounting major, one of significant changes is the emergence of government accounting in curriculum with the subject "accounting practice of the institution and local government agencies". The standard competency for vocational students related to this subject is students can be able in preparing local government financial statement. The problem is government accounting is a new thing for accounting teachers from vocational teachers, which they never teach before. This study aimed to use capacity building and workshop to improve teachers' understanding in preparing local government financial statement. Research methods used is an experiment, which classified as pre-experimental (non design) by the method of the one group pretest - post test design. The results indicated that there are differences in teachers' understanding in preparing local government financial statement before and after got capacity building and workshop. It can be concluded that capacity building and workshop can improve the teachers' understanding in preparing local government financial statement, so that the teachers' should be ready to teach the new subject "accounting practice of the institution and local government agencies".
\end{abstract}

Keywords: capacity building, government accounting, new curriculum, vocational teachers, workshop

\section{Introduction}

In Indonesia there are several types of upper secondary education, i.e. senior high schools, vocational secondary school, Madrasah Aliyah and Vocational Madrasah Aliyah. Vocational secondary school is a form of formal education unit organizes vocational or skills-based education. Unlike the senior high schools and others, vocational schools more focus on working world oriented, though not rare some of graduates are choosing to continue in college.

Success of graduates/students largely determined by the teacher, so also in vocational schools whose primary purpose is preparing graduates who are ready to enter the field of work and developing a professional attitude in accordance with the field the expertise has been provided in all schools. However, lessons (provision of science) provided by the teacher in the school must comply with the set in the curriculum. Curriculum changes and adjustments always happens due to the development of education and the development needs of its stakeholders. With the curriculum changes then consequently push teachers to prepare themselves for the changes, both in terms of learning methods, material or changes of subjects taught.

The issuance of SK Director General Dikdasmen No. 130/D/KEP/KR/2017 about the latest Vocational Schools Curriculum Structure since 10 February 2017 can be seen as a new challenges for vocational schools. The structure of the curriculum is the arrangement or building of various subjects required to form one competence that is arranged according to the grouping, sequence, and certain intensity. In majoring accounting and financial institutions experienced a change in part of the competency expertise. 
A change is the emergence of the subject "accounting practice of the institution and local government agencies" which will be taught in classes XI and XII.

Changes in the structure of the new curriculum expected to expand world work for graduates of the vocational schools. The occurrence of the subject "accounting practice of the institution and local government agencies" are expected to prepare graduates from vocational schools can work in the institutions and agencies of government. So graduates students from vocational schools with accounting areas of expertise no longer can only work on a business sector such as of merchandises and services companies, but also the public sector particularly acceptable in government.

The problem arises since government accounting is a new topic in curriculum structure for vocational school; attracts attentions from teachers. In accordance with the general provisions of UU No.14 in 2005 about Teachers and Lecturers, teacher is a professional educator with the main task of educating, teaching, guiding, directing, training, assessing and evaluating learners in early childhood education path of formal education, elementary education, and secondary education. Given the importance of the duties of teachers, then teachers are required to develop the science of knowledge.

Many researchers has proven that professional teachers significantly influence on vocational students' achievement (Bakar, 2018). This is in line with Ingvarson e al (2005) that states improving teacher professionalism is seen as a vital component in enhancing the quality of teaching and learning at schools. Brown (2000) states that modifications in the workroom needs continual teachers' professional development as means of skill upgrading. One of strategy that vocational teachers can do in improving their professionalism is participate in workshop or conference; workshops and conference allow teacher for mutual learning and sharing materials (Brown, 2000).

On the other hand, the development of governmental accounting runs very rapidly. One of them is the publication of the Government Regulation Number 71 in 2010 with accrual-based accounting standards. With the development of related regulations of government accounting, then vocational teachers especially majoring in accounting should update the accounting knowledge of governance and development, because for these vocational accounting teachers has not been too focused on it caused these subjects do not yet exist in the curriculum. However, now the subjects already entered in the curriculum structure of 2017, then it means that the teacher "had to" should update or learn about government accounting.

Based on description of the problem above, it can be concluded that the updating of knowledge teachers against regulations and the latest developments of the science of government accounting becomes very important. To reduce the problem as mentioned above, capacity building and workshop on the regulation and development of the latest government accounting for science teachers is still badly needed. This research will try to use capacity building and workshop as treatment in in order to improve vocational teachers understanding in government accounting, especially in preparing local government financial statement. The remainder of this paper is organized as follows. The next section presents the research methods and is followed by results and discussion. The final section concludes the paper by recommending some limitations and suggestions for future research.

\section{Methods}

Research methods used in this research is a method of experimentation. Experimental method is a method of research that is used to search for a particular treatment influence against the other in conditions completely (Sugiyono 2011:72). Experimental design to be used in this research is a type of pre-experimental (nondesign) by the method of the one group pretest - posttest design. On the one group pretest - posttest design there is a pre test prior to treatment (the treatment), the results of treatment can be assessed more accurately because it can be compared with prior treatment. Variable treatment in this 
study was the use of capacity building and workshop about preparing local government financial statement. The design of chart form is as follows:

\begin{tabular}{|c|c|c|}
\hline 01 & $\mathrm{X}$ & 02 \\
\hline Pretest & Treatment & Posttest \\
\hline
\end{tabular}

The following steps in this experiment research referring to Gay (in Hidayat, 2001) explain as below:

1. The existence of a significant problem for the researched.

The emergence of government accounting as part of new curriculum structure for vocational schools in majoring accounting based on the publications of SK Dirjen Dikdasmen No.130/D/KEP/KR/2017 with the name of new subject "accounting practice of the institution and local government agencies" which have never taught before; so that accounting teachers" should prepare themselves for this.

2. The selection of the subject enough to be divided in groups of experiments.

The subject in this study are accounting teachers from vocational schools in West Sumatera Province. The criteria for participants in this study is accounting teachers from vocational schools from West Sumatera Province who will teach the new subject "accounting practice of the institution and local government agencies". Thera 46 participants join in this research as representatives from 18 city/district in West Sumatera Province.

3. The making or development instruments.

The instruments used in this research was capacity building and workshop about preparing local government financial statement.

4. The selection of design research.

Design research is the one group pretest - posttest design.

5. Execution of the procedure.

The initial procedure in this study is to use capacity building and workshop about preparing local government financial statement. This procedure will last for 2 days. At the beginning, researchers will conduct a pre test which consist of 30 multiple questions about the concept of preparing local government financial statement to find out accounting teachers' understanding about preparing local government financial statement. Then, accounting teachers' will get capacity building and workshop about preparing local government financial statement. At the end of the meetings will be conducted post test to see the influence of using capacity building and workshop about preparing local government financial statement.

6. Doing data analysis.

To see the effects of capacity building and workshop about preparing local government financial statement, then data analysis will be performed with a different test, that is, to see if there is a difference on understanding about preparing local government financial statement before and after got capacity building and workshop about preparing local government financial statement. Then the hypothesis presented in this study is:

Ha: there is a difference on accounting teachers' understanding about preparing local government financial statement before and after got capacity building and workshop about preparing local government financial statement courses.

\section{Results and Discussions}

The following is a description of participants in this study. Based on the data in table 1, shown that the majority of participants were female, as many as 42 people or $91.30 \%$ of all participants while the number of male participants only 4 people or $8.70 \%$ of total participants. So it can be inferred that the majority of vocational teachers with accounting major who became participants on this study were female. Based on 
table 1, it can be seen that only 6 people or $13.04 \%$ who has teaching experience in less than five years. While a number of the other 13 people or $28.26 \%$ has been teaching accounting during the period between 5 to 10 years, 14 people or $30.43 \%$ has taught accounting for 10 to 15 years even the rest as many as 13 people or $28.26 \%$ have had teaching experience of more than 15 years. So it can be concluded that participants in this study aren't a junior accounting teachers but mostly it are teachers who had experienced teaching accounting for more than 5 years.

Table 1 Descriptions of Participants

\begin{tabular}{lll}
\hline Gender & Male & $8.70 \%$ \\
& Female & $91.30 \%$ \\
\hline Teaching & $0 \leq 5$ & $13.04 \%$ \\
experience & $\geq 5-10$ & $28.26 \%$ \\
& $\geq 10-15$ & $30.43 \%$ \\
& $>15$ & $28.26 \%$ \\
\hline
\end{tabular}

This research also gather some information related to the knowledge of the participants to the materials of government accounting especially about the preparation of local government financial statements:

Table 2 Knowledge of Government Accounting

\begin{tabular}{lcccc}
\hline \multicolumn{1}{c}{ Question } & \multicolumn{2}{c}{ Ever } & \multicolumn{2}{c}{ Never } \\
\cline { 2 - 5 } & Amount & \% & amount & \% \\
\hline $\begin{array}{l}\text { Have you ever taught government accounting } \\
\text { courses? }\end{array}$ & 1 & $2.17 \%$ & 45 & $97.83 \%$ \\
\hline $\begin{array}{l}\text { Had Mr / Mrs attended training about preparation } \\
\text { of local government financial statements? }\end{array}$ & 0 & $0.00 \%$ & 46 & $100.00 \%$ \\
\hline & \multicolumn{2}{c}{ Yes } & \multicolumn{2}{c}{ No } \\
\hline & Amount & amount & \% \\
\hline $\begin{array}{l}\text { Do you know about accrual-based accounting in } \\
\text { government accounting? }\end{array}$ & 4 & $8.96 \%$ & 42 & $91.31 \%$ \\
\hline
\end{tabular}

Based on table 2 above, there are 3 important information gathered from participants in this study related to their knowledge of government accounting. First, government accounting is a new things for participants or accounting teachers from vocational schools at West Sumatra Province joined in this study; it can be shown from their answer to the first question where only 1 participants who ever taught lessons related to government accounting, while others never taught government accounting before. Second, all participants never joined training related to topic government accounting, it can be prove from the answer for question number 2. Third, limitedness knowledge from participants related to development of government accounting; which can be trace from the answer for questions number 3.

Regardless to the challenges of new curriculum structure in 2017 shown the importance of capacity building and workshop about the preparation of the local government financial statements, since most of participants has never received training related to the this topic and the majority of participants also has not yet find out the latest updates from government accounting; whereas the new curriculum 2017 demanding participant to the new subject "accounting practice of the institution and local government agencies". Following are the results of the comparison of pre-test and post-test to find out the level of participants' understanding related to government accounting, especially about preparing the local government financial statements: 
Table 3 Comparison of pre-test and post-test

\begin{tabular}{c|c|c|c|}
\hline Description & Mean & N & Std. Dev \\
\hline Pre Test & $\mathbf{1 1 , 4 8}$ & $\mathbf{4 6}$ & $\mathbf{2 , 7 3 9}$ \\
\hline Post Test & $\mathbf{2 1 , 0 4}$ & $\mathbf{4 6}$ & $\mathbf{3 , 6 5 1}$ \\
\hline
\end{tabular}

Based on the table 3 above can be seen that average score of pre-test is only 11.48 for 30 questions; whereas after getting capacity building and workshop about the preparation of local government financial statements there is increases in score which became 21.04. This indicated that capacity building and workshop about preparation of local government financial statement can enhance participants understanding' about government accounting especially about preparation of local government financial statement in this study. This research also check statistically to answers the hypothesis in this research. Before performing a difference test it should checked for data homogeneity and normality. The following are the results of the test of normality and its homogeneity:

\section{Test of normality}

Table 4 One-Sample Kolmogorov-Smirnov Test

\begin{tabular}{|c|c|c|c|}
\hline & & skor_pre_test & skor_post_test \\
\hline $\mathrm{N}$ & & 46 & 46 \\
\hline \multirow[t]{2}{*}{ Normal Parameters $\mathrm{a}, \mathrm{b}$} & Mean & 11.48 & 21.04 \\
\hline & $\begin{array}{l}\text { Std. Devi } \\
\text { ation }\end{array}$ & 2,739 & 3,651 \\
\hline \multirow{3}{*}{$\begin{array}{l}\text { Most Extreme } \\
\text { Differences }\end{array}$} & Absolute &, 156 &, 170 \\
\hline & Positive & 156 &, 118 \\
\hline & Negative &,- 105 &,- 170 \\
\hline \multicolumn{2}{|l|}{ Test Statistic } &, 156 &, 170 \\
\hline \multicolumn{2}{|l|}{ Asymp. Sig. (2-tailed) } & $007^{c}$ &, $002^{\mathrm{c}}$ \\
\hline \multicolumn{4}{|c|}{ a. Test distribution is Normal. } \\
\hline \multicolumn{4}{|l|}{ b. Calculated from data. } \\
\hline \multicolumn{4}{|c|}{ c. Lilliefors Significance Correction. } \\
\hline
\end{tabular}

Based on table 4, it can be shown that the value of asymp. sig (2-tailed) data from pre-test is 0.007 while post-test is 0.002 where value of asymp. sig (2-tailed) smaller than 0.05 ; so that it can be concluded that both data pre-test and post-test is not distributed normally and this study will use non parametric analysis.

Test of homogeneity

Based on table 5 below, it can be shown that the value of sig of this is 0.982 where the value of the sig > $0.05 \alpha$ it means that value of sig is bigger than 0,05 , then it can be said that the data homogeneous.

Table 5 Test of Homogeneity

\begin{tabular}{llllll}
\hline \multicolumn{5}{c}{ ANOVA } \\
\hline & $\begin{array}{l}\text { Mean } \\
\text { Sum of } \\
\text { Squares }\end{array}$ & Df & $\begin{array}{l}\text { Squar } \\
\text { e }\end{array}$ & F & Sig. \\
\hline Between Groups & 34,454 & 12 & 2,871 &, 313 &, 982 \\
\hline Within Groups & 303,024 & 33 & 9,183 & & \\
\hline Total & 337,478 & 45 & & & \\
\hline
\end{tabular}




\section{Test of difference}

Based on table 6, it shown Wilcoxon ranks which divided into 3 criteria such as negative ranks, positive ranks and ties. The number of negative ranks is 0 means that no one participants get lowest score after getting capacity building and workshop about preparation of local government financial statement. There are 44 of participants in positive ranks, means that 44 of participants or majority get post-test score is higher than pre-test score, while 2 of participants in ties means there are 2 participants got the same score for their pre-test and post-test. The result of Wilcoxon ranks support that capacity building and workshop can improve participants understanding' about government accounting especially about preparing of local government financial statement.

Table 6 Wilcoxon Ranks

\begin{tabular}{|c|c|c|c|c|}
\hline \multicolumn{5}{|l|}{ Ranks } \\
\hline & & $\mathbf{N}$ & Mean Rank & Sum of Ranks \\
\hline \multirow[t]{4}{*}{ skor_post_testskor_pre_test } & Negative Ranks & $0^{\mathrm{a}}$ & ,00 & 00 \\
\hline & Positive Ranks & $44^{\mathrm{b}}$ & 22,50 & 990,00 \\
\hline & Ties & $2^{\mathrm{c}}$ & & \\
\hline & Total & 46 & & \\
\hline \multicolumn{5}{|c|}{ a. skor_post_test $<$ skor_pre_test } \\
\hline \multicolumn{5}{|c|}{ b. skor_post_test > skor_pre_test } \\
\hline c. skor_post_test $=$ skor_pre_ & & & & \\
\hline
\end{tabular}

\begin{tabular}{ll}
\hline Test Statistics & \\
\hline & $\begin{array}{l}\text { skor_post_test - } \\
\text { skor_pre_test }\end{array}$ \\
\hline$Z$ & $-5,780^{\mathrm{b}}$ \\
\hline Asymp. Sig. (2-tailed) &, 000 \\
\hline a. Wilcoxon Signed Ranks Test \\
\hline b. Based on negative ranks.
\end{tabular}

To determine the answer of hypothesis in this study can be seen from the significant value from Wilcoxon test which identified 0000. It means that significant value smaller than 0.05 ; so that the hypothesis in this study is acceptable. This result prove that there is a difference in participants understanding before and after getting the capacity building and workshops on the preparing local government financial statement.

\section{Conclusions}

Government accounting is new things for accounting teachers from vocational schools in West Sumatera province. Most of the teachers never taught government accounting and never joined any training or workshop that related to this topic. Capacity building and workshop are use to improve their understanding in government accounting especially preparing local government financial statement. The results indicated that a) there is a difference in teachers' understanding in preparing local government financial statement before and after got capacity building and workshop; and b) capacity building and workshop can improve the teachers' understanding in preparing local government financial statement, so that the teachers' be ready to teach the new subject "accounting practice of the institution and local government agencies". Some limitations in this research are: a) this research is only using multiple choice question for pre-test and post-test; $b$ ) the time limitations in capacity building and workshop, so that has not shown maximum results; and c) types of experiment that was done in this study a new type of preexperimental (nondesign) by the method of the one group pretest - posttest design. So, the advices to 
next researchers are: a) the next research can design more complex cases related to government accounting to checked participants understandings in preparation of local government financial statement such as a comprehensive case study; b) subsequent research can develop other type of research experiments such as true-posttest only control include experimental design, pretest-control group design or other types of research experiments.

\section{References}

Brown, Bettina Lankard. (2000). Vocational Teacher Professional Development Practice Application Berif No.11.

Ingvarson, et al. (2005). Factors Affecting the Impact of Professional Development Programs on Teachers' Knowlegde, Practice, Student Outcomes \& Efficacy. Education Policy Analysis Archieves Vol.13 No.10

Hidayat, Akhmad. 2011. Penelitian Eksperimen.http://www.statistikian.com/2012/10/penelitianexperimen.html

SK Dirjen Dikdasmen No.130/D/KEP/KR/2017 tentang Struktur Kurikulum SMK Terbaru

Republik Indonesia. 2005. Undang-Undang Nomor 14 Tahun 2005 tentang Guru dan Dosen.

Republik Indonesia. 2010. Peraturan Pemerintah Nomor 71 tahun 2010 tentang Standar Akuntansi Pemerintahan

Sugiyono. (2011). Metode Penelitian Kuantitatif Kualitatif dan RED. Bandung: Alfabeta. 